\title{
Relationship between Clinical Systemic Lupus Erythematosus Symptoms and Indexes of Blood, Renal Function, Liver Function and Immunology Q Lu ${ }^{1,2}, \mathrm{H}$ Yang ${ }^{3}, \mathrm{Y} \mathrm{Qu}^{2}, \mathrm{Y} \mathrm{Ding}^{2}, \mathrm{X} \mathrm{Kang}^{2}, \mathrm{X} \mathrm{Pu}{ }^{2}$
}

\begin{abstract}
Objective: This paper aimed to study the relationships between clinical systemic lupus erythematosus (SLE) symptoms and indexes of blood, renal function, liver function and immunology.

Methods: Total 117 SLE patients were collected, and clinical symptoms and biochemical indexes of blood, renal function, liver function and immunology were determined. Then, adaptive lasso analysis was used to analyse the potential relationship between the clinical symptoms of SLE and biochemical indexes.

Results: The present results indicated that pleurisy is closely related to the red blood cells (RBC), haemoglobin $(\mathrm{Hb})$ and urea nitrogen $(\mathrm{BUN})$ with the $\left|\beta_{\mathrm{j}}\right|$ values of $0.0045,0.0168$ and 0.0064 , respectively; oedema is closely related to the albuminuria and cylindruria with $\left|\beta_{\mathrm{j}}\right|$ values of 0.0198 and 0.1170 ; alopecia has closely correlations with liver damage and aspartate aminotransferase (AST), $\left(\left|\beta_{\mathrm{j}}\right|\right.$ values were 0.0033 and 0.0104$)$; fever is correlated to liver damage $\left(\left|\beta_{\mathrm{j}}\right|\right.$ values were 0.0011$)$; raynaud phenomenon is closely correlated to the triglycerides (TG) and Anti-U1 Ribonucleoprotein (u1RNP) with $\left|\beta_{\mathrm{j}}\right|$ value of 0.0012 and 0.0012 ; facial redness and arthralgia have close correlations with SSA $\left(\left|\beta_{\mathrm{j}}\right|\right.$ value were 0.3580 and 0.0047 ; arthritis and pericarditis are closely related to antinucleosome antivodies (AnuA) with $\left|\beta_{\mathrm{j}}\right|$ values of 0.0038 and 0.0026 .

Conclusion: The present study indicated that some biochemical, including RBC, $\mathrm{Hb}, \mathrm{BUN}$, albuminuria and cylindruria, liver damage, AST, TG, SSA, AnuA and u1RNP, are closely to the prognosis of SLE and it's important to control these biochemical indexes during the treatment period.
\end{abstract}

Keywords: Adaptive lasso analysis, biochemical indexes, clinical symptoms, systemic lupus erythematosus

From: ${ }^{1}$ Department of Dermatology and Venereology, Anhui Medical University, Hefei 230000, PR China, ${ }^{2}$ Department of Dermatology and Venereology, People's Hospital of Xinjiang Uygur Autonomous Region, Urumqi 830000, PR China and ${ }^{3}$ Department of Dermatology and Venereology, North Branch of People's Hospital of Xinjiang Uygur Autonomous Region, Urumqi 830000, PR China.

Correspondence: Professor X Pu, Department of Dermatology and Venereology, People's Hospital of Xinjiang Uygur Autonomous Region, Urumqi 830000, PR China. Email: puxmx668hp@126.com 


\section{INTRODUCTION}

It is well known that systemic lupus erythematosus (SLE) is a typical chronic life threatening inflammatory autoimmune disease $(1,2)$. Systemic lupus erythematosus is characterized by excessed release of autoantibodies which might result in end organ damage $(3,4)$. It is estimated that the SLE incidence is approximately 50-100 per 100000 people with a ratio of 9:1 in female to male $(5,6)$. Currently, a large number of investigations have devoted into SLE, and great improvements have been achieved in the diagnosis and treatment of SLE (7). Currently, diagnostic criteria for definite diagnosis of SLE mainly include clinical symptoms, biochemical indexes (blood parameters, renal \& liver functions indexes and immunological indexes).

The clinical symptoms are commonly the first manifestations of SLE, such as facial redness, rush in trunk and limbs, thirst, arthralgia, arthritis, photaesthesia, oral ulcer, oedema, dryness of eye, alopecia, fever, raynaud phenomenon, pericarditis, pleurisy and multiple serositis (8). In addition, the biochemical indexes, including blood indexes, renal and liver functions indexes and immunological indexes, are very important evidences for finding early stage SLE $(8,9)$. There are might be some potential relationship between the clinical symptoms of SLE and biochemical indexes. However, there is no report about the relationship between clinical SLE symptoms and indexes of blood, renal function, liver function and immunology. Thereby, in this present study, 117 SLE patients were enrolled and the adaptive lasso analysis was used to analyse the potential relationship between the clinical symptoms of SLE and biochemical indexes. This research has significant reference value for the early diagnosis and prognosis of SLE clinically. 


\section{METHODS AND MATERIALS}

\section{Subjects and experimental protocol}

Total 117 patients admitted to the People's Hospital of Xinjiang Uygur Autonomous Region with a definite diagnosis of SLE according to clinical symptoms and biochemical examinations. The basic characteristics and clinical symptoms of SLE patients are described in Table 1. All the patients collected were required to read and sign an informed consent forms voluntarily before enrollment and all our experimental protocols were approved by the ethical committee of the People's Hospital of Xinjiang Uygur Autonomous Region (No. 201306-s007).

Furthermore, vein blood samples of the SLE patients were collected. The blood parameters were analysed by automated haematology analyser including white blood cells (WBC), red blood cells (RBC), platelet (PLT) and haemoglobin (Hb) [Table 2]. The renal and liver functions indexes were determined by automatic biochemical analyser, including creatinine, albuminuria, cylindruria, urea nitrogen (BUN), hematuria, pyuria (Table 3), total cholesterol (TC), high density lipoprotein (HDL), low density lipoprotein (LDL), albumin (ALB), globulin (GLO), Triglyceride, gamma-glutamyl transpeptidase (GGT), glutamic oxalacetic transaminase (AST), glutamic-pyruvic transaminase (ALT) and alkaline phosphatase (ALP) (Table 4).

Immunological indexes including complement (C) 3, C4, C1q, immunoglobulin (Ig) G, anti-cardiolipin antibody (ACL), $\operatorname{IgM}, \operatorname{IgA}$ and anti-unc leosom e antibody (AnuA), antiSjogren's syndrome (SS) A antibody, SSB, anti-RO52 antibody, anti-Jo-1 antibody, anti-u1 RNP antibody, anti-centromere protein B (CENP-B), anti-Sm antibody, anti-Scl70 antibody, anti-histone antibody and perinuclear anti-neutrophil cytoplasmic antibody (pANCA) were determined by enzyme linked immunosorbent assays (ELISA), and anti-nuclear antibody (ANA) titer and anti-double-stranded DNA antibodiy (ds DNA) were determined by indirect immunofluorescence assays. Systemic lupus erythematosus disease activity index (SLEDAI) 
scores were evaluated according to reported methods [10] (Table 5).

\section{Data analysis}

The data of clinical symptoms and biochemical indexes of SLE were regressed by using adaptive lasso and the adaptive lasso estimator was expressed as previous report (11):

$$
\hat{\beta}=\underset{\beta}{\arg \min }\|y-X \beta\|_{2}^{2}+\lambda \sum_{j=1}^{p} \omega_{j}\left|\beta_{j}\right|
$$

Where $\omega_{j}(j=1, \ldots, p)$ are the adaptive data-driven weights, $p$ is the number of predictor variables, $\lambda$ is the tuning parameter.

Due to the disease status is a binary response which follows a binomial distribution, we used LQA algorithm to obtain the sparse shrinkage estimate based on generalized linear models (12). The tuning parameter $\lambda$ can be selected a grid of values, with values of $\lambda$ selected from $[0.1,1.5]$, using bayesian information criterion (BIC). The weights allow the adaptive lasso to apply different amounts of shrinkage to different coefficients and hence to more severely penalize coefficients with small values. To adjust effect of nation, gender and age, weight of three factors were set to zero, accept the defaults for the remainder. $\left|\beta_{\mathrm{j}}\right|>0.001$ was used as the critical value, this measure can select the significant variables while filtering the weak ones.

\section{RESULTS}

\section{Relationship between SLE symptoms and blood parameters}

As can be seen from the Table $6,\left|\beta_{\mathrm{j}}\right|$ values of the relationship between SLE symptoms and blood parameters were shown. The results indicated that pleurisy is closely related to the RBC and $\mathrm{Hb}$ with the $\left|\beta_{\mathrm{j}}\right|$ values of 0.0045 and 0.0168 , respectively. 


\section{Relationship between SLE symptoms and renal functions}

Relationships between SLE symptoms and renal functions were described in Table 6. From the present results, pleurisy has a close correlation to BUN with the $\beta_{\mathrm{j}} \mid$ value of 0.0064 . In addition, the present results also showed that oedema is closely related to the albuminuria and cylindruria and the $\left|\beta_{\mathrm{j}}\right|$ values were 0.0198 and 0.1170 , respectively.

\section{Relationship between SLE symptoms and liver functions indexes}

As can be seen from the Table 7, relationships between SLE symptoms and liver functions indexes were described. The present research indicated that alopecia has closely correlations with liver damage and AST $\left(\left|\beta_{\mathrm{j}}\right|\right.$ values were 0.0033 and 0.0104 , respectively). Furthermore, fever is correlated to the liver damage $\left(\beta_{\mathrm{j}} \mid\right.$ values were 0.0011$)$. Besides, raynaud phenomenon is closely correlated to the TG with the $\left|\beta_{\mathrm{j}}\right|$ value of 0.0012 .

\section{Relationship between SLE symptoms and immunological indexes}

Table 8 described the $\beta_{\mathrm{j}} \mid$ values of the relationships between SLE symptoms and immunological indexes. From the results, facial redness and arthralgia have close correlations with SSA $\left(\left|\beta_{\mathrm{j}}\right|\right.$ value were 0.3580 and 0.0047 , respectively). Furthermore, arthritis and pericarditis are closely related to the AnuA with the $\left|\beta_{\mathrm{j}}\right|$ values of 0.0038 and 0.0026 , respectively. In addition, raynaud phenomenon has close correlation with u1RNP $\left(\left|\beta_{\mathrm{j}}\right|\right.$ value was 0.0012$)$. Besides, pleurisy and oedema are closely related to SLEDAI scores $\left(\left|\beta_{\mathrm{j}}\right|\right.$ value were 0.0413 and 0.0518 , respectively). 


\section{DISCUSSION}

This paper investigated the relationships between clinical SLE symptoms and indexes of blood, renal function, liver function and immunology for the first time, and found that clinical SLE symptoms are closely correlated to some biochemical indexes including RBC, Hb, BUN, albuminuria and cylindruria, liver damage, AST, TG, SSA, AnuA, u1RNP, etc. Thereby, the present research indicated that these biochemical indexes might be closely to the prognosis of SLE and it is important to control these biochemical indexes during the treatment period.

Because the disease status is commonly affected by a small number of factors, penalized regression would shrink some factors of coefficient vector to zero, which indicate that the corresponding factors are not associated with the disease status $(11,12)$. Lasso is a useful technique for simultaneous estimation and variable selection. Furthermore, adaptive lasso is a novel version of lasso whose weights is used for penalizing different coefficients, and it have been demonstrated that adaptive lasso could be used to select the significant variables while filtering the weak ones $(13,14)$. In this study, adaptive lasso was used to penalty function which can adjust effect of some factors by different weights and $\left|\beta_{\mathrm{j}}\right|>0.001$ was used as the critical value.

It's well-known that SLE would result in multi-organs' disorders or damages, such as heart, liver, skin, digestive tract and kidney $(15,16)$. Therefore, SLE leads to various biomarkers of the function of multi-organs. Finding the significant biomarkers of a disease is essential for the controlling and treatment of this disease (17). In this present research, based on adaptive lasso analysis, some significant biochemical indexes have been found to have close relationships with the clinical symptoms of SLE, and these indexes including RBC, Hb, BUN, albuminuria and cylindruria, liver damage, AST, TG, SSA, AnuA, u1RNP, etc. Importantly, these biochemical indexes might be closely to the prognosis of SLE and therefore controlling these biochemical indexes during the treatment period might be beneficial for treating SLE. 


\section{CONCLUSION}

In conclusion, the present study indicated that some biochemical, including RBC, $\mathrm{Hb}, \mathrm{BUN}$, albuminuria and cylindruria, liver damage, AST, TG, SSA, AnuA and u1RNP, are closely to the prognosis of SLE and it's important to control these biochemical indexes during the treatment period.

\section{AUTHORS' NOTE}

The authors declare that there is no conflict of interests.

\section{REFERENCES}

1. Zhou XJ, Nath SK, Qi YY, Sun C, Hou P, Zhang YM et al. Novel identified associations of RGS1 and RASGRP1 variants in IgA Nephropathy. Sci Rep 2008; 6: 35781.

2. Motawi TK, Mohsen DA, El-Maraghy SA, Kortam MA. MicroRNA-21, microRNA181a and microRNA-196a as potential biomarkers in adult Egyptian patients with systemic lupus erythematosus. Chem Biol Interact 2016; 260: 110-16.

3. Hersh AO, Alarcón GS, Bonetto C, Pernus YB, Kucuku M, Santuccio C et al. Systemic Lupus Erythematosus: Case definition and guidelines for data collection, analysis, and presentation of immunization safety data. Vaccine 2016; 34: 6572-81.

4. Mendoza-Pinto C, Pirone C, van der Windt DA, Parker B, Bruce IN. Can we identify who gets benefit or harm from mycophenolate mofetil in systemic lupus erythematosus? A systematic review. Semin Arthritis Rheum, doi: 10.1016/j.semarthrit.2017.01.009, 2017. 
5. Danchenko N, Satia JA, Anthony MS. Epidemiology of systemic lupus erythematosus: a comparison of worldwide disease burden. Lupus 2006; 15: 308-18.

6. do Nascimento NM, Juste-Dolz A, Grau-García E, Román-Ivorra JA, Puchades R, Maquieira A et al. Label-free piezoelectric biosensor for prognosis and diagnosis of Systemic Lupus Erythematosus. Biosens Bioelectron 2017; 90: 166-73.

7. Canora J, García M, Mitjavila F, Espinosa G, Suárez S, González-León R et al. Clinical characteristics during diagnosis of a prospective cohort of patients with systemic lupus erythematosus treated in Spanish Departments of Internal Medicine: The RELES study. Rev Clin Esp 2017; 217: 7-14.

8. Zhang LY, Dong L. The progress of diagnosis of systemic lupus erythematosus in laboratory. J Top Med 2012; 12: 1418-20.

9. Xie JM, Mo SL, Ye PJ. Analysis and comparison of serum immune index in patients with rheumatoid arthritis or systemic lupus erythematosus. Chin Med Hera 2012; 9: $43-7$.

10. Zhou JQ, Jiang H. Feasibility of SLEDAI-2000 and BILAG-2004 scoring systems for assessing renal disease activity in children with lupus nephritis. Chin J Contemp Pediatr 2012; 14: 775-9.

11. Zhou H. The adaptive lasso and its oracle properties. J Am Stat Assoc 2006; 101: $1418-29$.

12. Fan JQ, Runze L. Variable selection via nonconcave penalized likelihood and its oracle properties. J Am Stat Assoc 2001; 96: 1348-60. 
13. Lu M, Zhou J, Naylor C, Kirkpatrick BD, Haque R, Petri WA Jr et al. Application of penalized linear regression methods to the selection of environmental enteropathy biomarkers. Biomark Res 2017; 5: 9.

14. Deng Y, Chang C, Ido MS, Long Q. Multiple imputation for general missing data patterns in the presence of high-dimensional data. Sci Rep 2016; 6: 21689.

15. Munroe ME, Vista ES, Merrill JT, Guthridge JM, Roberts VC, James JA. Pathways of impending disease flare in African-American systemic lupus erythematosus patients. $\mathbf{J}$ Autoimmun 2017; 78: 70-8.

16. Leone A, Radin M, Almarzooqi AM, Al-Saleh J, Roccatello D, Sciascia S et al. Autologous hematopoietic stem cell transplantation in Systemic Lupus Erythematosus and antiphospholipid syndrome: a systematic review. Autoimmun Rev, doi: 10.1016/j.autrev.2017.03.008, 2017.

17. Zou ZH, Fu L, Gu FF, Ye ZX. Relationship between biochemical indicators and clinical symptoms of malignant obstructive jaundice patients. J Nurs Sci 2012; 27: 2022. 
Table 1: Baseline demographics and clinical symptoms of the collected patients

\begin{tabular}{|c|c|c|c|}
\hline \multicolumn{4}{|c|}{ Baseline demographics and clinical symptoms $(n=117)$} \\
\hline Age & & & \\
\hline$<20$ & 11 & Yes & 20 \\
\hline $20-50$ & 91 & No & 97 \\
\hline$>50$ & 15 & & \\
\hline Gender & \multicolumn{3}{|c|}{ Dryness of eye } \\
\hline Male & 9 & Yes & 6 \\
\hline Female & 108 & No & 111 \\
\hline Thirst & \multicolumn{3}{|c|}{ Alopecia } \\
\hline Yes & 12 & Yes & 44 \\
\hline No & 105 & No & 73 \\
\hline Facial redness & \multicolumn{3}{|c|}{ Fever } \\
\hline Yes & 55 & Yes & 55 \\
\hline No & 62 & No & 62 \\
\hline Rush in trunk and limbs & \multicolumn{3}{|c|}{ Raynaud phenomenon } \\
\hline Yes & 22 & Yes & 19 \\
\hline No & 95 & No & 98 \\
\hline Arthralgia & \multicolumn{3}{|c|}{ Pericarditis } \\
\hline Yes & 72 & Yes & 15 \\
\hline No & 42 & No & 102 \\
\hline Arthritis & \multicolumn{3}{|c|}{ Pleurisy } \\
\hline Yes & 64 & Yes & 18 \\
\hline No & 53 & No & 99 \\
\hline Photaesthesia & \multicolumn{3}{|c|}{ Multiple serositis } \\
\hline Yes & 14 & Yes & 7 \\
\hline No & 103 & No & 110 \\
\hline Oral ulcer & & & \\
\hline Yes & 28 & & \\
\hline No & 89 & & \\
\hline
\end{tabular}


Table 2: Results of blood examinations of the collected patients

\begin{tabular}{llllclll}
\hline \multicolumn{1}{c}{ WBC } & \multicolumn{2}{c}{ Blood indices $(\mathbf{n = 1 1 7})$} \\
\multicolumn{1}{c}{$\mathbf{R B C}$} & \multicolumn{1}{c}{ PLT } & \multicolumn{2}{c}{ Hb } \\
\hline$<3 \times 10^{9} / \mathrm{L}$ & 18 & $<3.5 \times 10^{12} / \mathrm{L}$ & 22 & $<100 \times 10^{9} / \mathrm{L}$ & 19 & $<110 \mathrm{~g} / \mathrm{L}$ & 43 \\
$3-4 \times 10^{9} / \mathrm{L}$ & 24 & $3.5-4.0$ & 36 & $100-200 \times 10^{9} / \mathrm{L}$ & 57 & $110-120 \mathrm{~g} / \mathrm{L}$ & 25 \\
$4-6 \times 10^{9} / \mathrm{L}$ & 31 & $4.0-4.5$ & 36 & $200-300 \times 10^{9} / \mathrm{L}$ & 27 & $120-130 \mathrm{~g} / \mathrm{L}$ & 31 \\
$6-10$ & 33 & $4.5-5.0$ & 22 & $>300 \times 10^{9} / \mathrm{L}$ & 14 & $130-160 \mathrm{~g} / \mathrm{L}$ & 16 \\
$>10 \times 10^{9} / \mathrm{L}$ & 11 & $>5.0 \times 10^{12} / \mathrm{L}$ & 1 & & & $>160 \mathrm{~g} / \mathrm{L}$ & 2 \\
\hline
\end{tabular}

Table 3: Results of renal function examinations of the collected patients

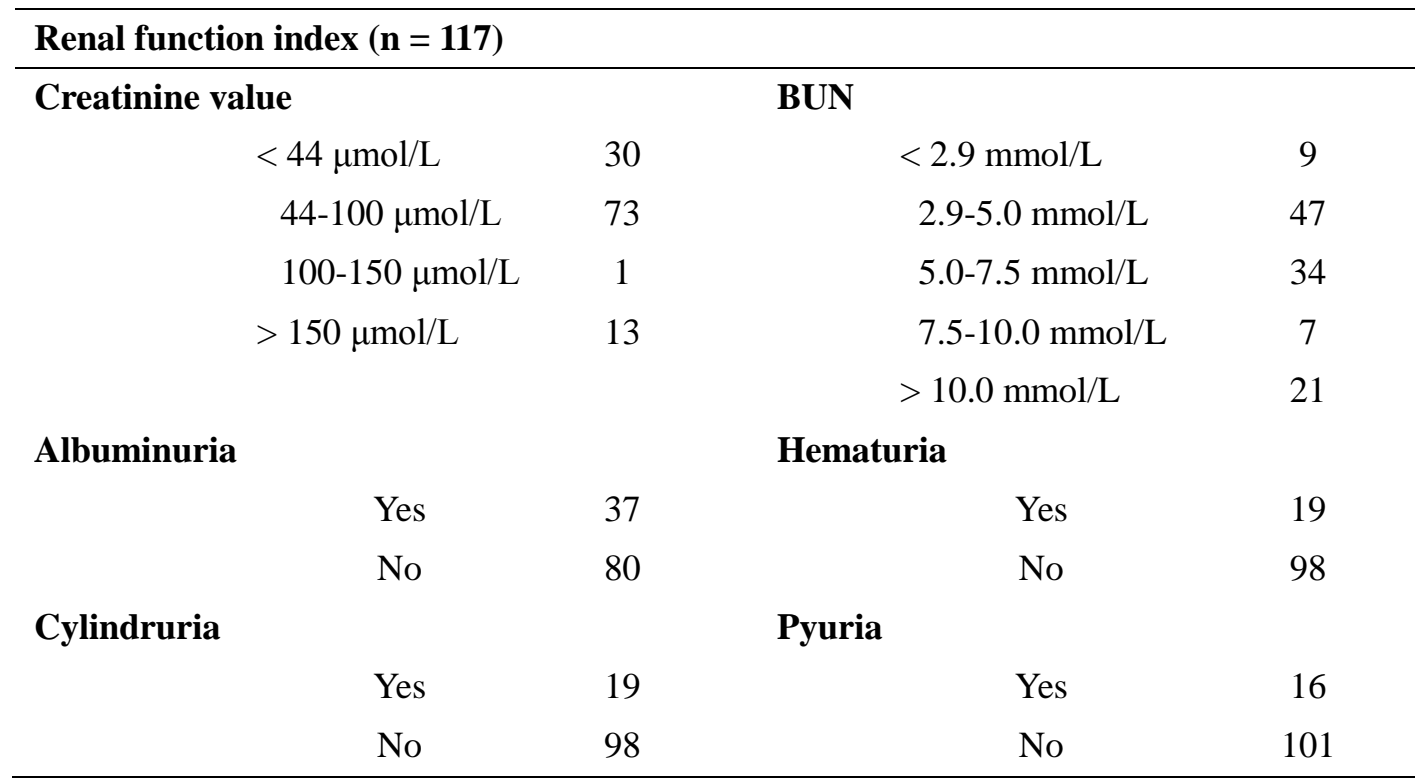


Table 4: Results of liver function examinations of the collected patients

\begin{tabular}{|c|c|c|c|}
\hline \multicolumn{4}{|c|}{ Liver function indices $(n=117)$} \\
\hline TC & & ceride & \\
\hline$<2.8 \mathrm{mmol} / \mathrm{L}$ & 17 & $<1.0 \mathrm{mmol} / \mathrm{L}$ & 12 \\
\hline $2.8-4.0 \mathrm{mmol} / \mathrm{L}$ & 34 & $1.0-1.8 \mathrm{mmol} / \mathrm{L}$ & 44 \\
\hline $4.0-6.0 \mathrm{mmol} / \mathrm{L}$ & 38 & $1.8-3.0 \mathrm{mmol} / \mathrm{L}$ & 24 \\
\hline$>6.0 \mathrm{mmol} / \mathrm{L}$ & 26 & $>3.0 \mathrm{mmol} / \mathrm{L}$ & 37 \\
\hline HDL & \multicolumn{2}{|c|}{ GGT } & \\
\hline$<1.0 \mathrm{mmol} / \mathrm{L}$ & 35 & $<20 \mathrm{~g} \mathrm{U} / \mathrm{L}$ & 41 \\
\hline $1.0-1.1 \mathrm{mmol} / \mathrm{L}$ & 11 & $20-40 \mathrm{U} / \mathrm{L}$ & 30 \\
\hline $1.1-1.5 \mathrm{mmol} / \mathrm{L}$ & 26 & $40-60 \mathrm{U} / \mathrm{L}$ & 12 \\
\hline $1.5-2.0 \mathrm{mmol} / \mathrm{L}$ & 9 & $60-100 \mathrm{U} / \mathrm{L}$ & 10 \\
\hline$>2.0 \mathrm{mmol} / \mathrm{L}$ & 36 & $>100 \mathrm{U} / \mathrm{L}$ & 24 \\
\hline LDL & & & \\
\hline$<1.5 \mathrm{mmol} / \mathrm{L}$ & 28 & $<20 \mathrm{~g} \mathrm{U} / \mathrm{L}$ & 34 \\
\hline $1.5-2.0 \mathrm{mmol} / \mathrm{L}$ & 16 & $20-40 \mathrm{U} / \mathrm{L}$ & 42 \\
\hline $2.0-3.0 \mathrm{mmol} / \mathrm{L}$ & 30 & $40-60 \mathrm{U} / \mathrm{L}$ & 20 \\
\hline $3.0-3.5 \mathrm{mmol} / \mathrm{L}$ & 4 & $60-100 \mathrm{U} / \mathrm{L}$ & 11 \\
\hline$>3.5 \mathrm{mmol} / \mathrm{L}$ & 39 & $>100 \mathrm{U} / \mathrm{L}$ & 10 \\
\hline ALB & & & \\
\hline$<20 \mathrm{~g} / \mathrm{L}$ & 11 & $<20 \mathrm{~g} \mathrm{U} / \mathrm{L}$ & 44 \\
\hline $20-30 \mathrm{~g} / \mathrm{L}$ & 21 & $20-40 \mathrm{U} / \mathrm{L}$ & 36 \\
\hline $30-35 \mathrm{~g} / \mathrm{L}$ & 27 & $40-60 \mathrm{U} / \mathrm{L}$ & 15 \\
\hline $35-40 \mathrm{~g} / \mathrm{L}$ & 37 & $60-100 \mathrm{U} / \mathrm{L}$ & 9 \\
\hline$>40 \mathrm{~g} / \mathrm{L}$ & 20 & $>100 \mathrm{U} / \mathrm{L}$ & 13 \\
\hline GLO & & & \\
\hline$<20 \mathrm{~g} / \mathrm{L}$ & 1 & $<30 \mathrm{~g} \mathrm{U} / \mathrm{L}$ & 3 \\
\hline $20-30 \mathrm{~g} / \mathrm{L}$ & 37 & $30-50 \mathrm{U} / \mathrm{L}$ & 29 \\
\hline $30-35 \mathrm{~g} / \mathrm{L}$ & 27 & $50-90 \mathrm{U} / \mathrm{L}$ & 56 \\
\hline $35-40 \mathrm{~g} / \mathrm{L}$ & 23 & $90-150 \mathrm{U} / \mathrm{L}$ & 14 \\
\hline$>40 \mathrm{~g} / \mathrm{L}$ & 29 & $>150 \mathrm{U} / \mathrm{L}$ & 15 \\
\hline \multicolumn{4}{|l|}{ Liver function damage } \\
\hline Yes & 23 & & \\
\hline No & 94 & & \\
\hline
\end{tabular}


Table 5: Results of immunological examinations and SLEDAI scores of the collected patients

\begin{tabular}{|c|c|c|c|c|c|}
\hline \multicolumn{6}{|c|}{ Immunological indices $(n=117)$} \\
\hline Complement C3 & & & & & \\
\hline$<0.2 \mathrm{~g} / \mathrm{L}$ & 11 & $<1 \mathrm{RU} / \mathrm{mL}$ & 28 & $<1 \mathrm{RU} / \mathrm{mL}$ & 39 \\
\hline $0.2-0.5 \mathrm{~g} / \mathrm{L}$ & 26 & $1-10 \mathrm{RU} / \mathrm{mL}$ & 25 & 1 - 5 RU/mL & 29 \\
\hline $0.5-0.8 \mathrm{~g} / \mathrm{L}$ & 35 & $10-20 \mathrm{RU} / \mathrm{mL}$ & 10 & $5-12 \mathrm{RU} / \mathrm{mL}$ & 8 \\
\hline $0.8-1.2 \mathrm{~g} / \mathrm{L}$ & 37 & 20-100 RU/mL & 6 & $12-40 \mathrm{RU} / \mathrm{mL}$ & 2 \\
\hline$>1.2 \mathrm{~g} / \mathrm{L}$ & 8 & $>100 \mathrm{RU} / \mathrm{mL}$ & 48 & $>40 \mathrm{RU} / \mathrm{mL}$ & 39 \\
\hline Complement C4 & & $\mathbf{u A}$ & & EDAI score & \\
\hline$<0.02 \mathrm{~g} / \mathrm{L}$ & 14 & $<1 \mathrm{RU} / \mathrm{mL}$ & 51 & $<4$ & 15 \\
\hline $0.02-0.1 \mathrm{~g} / \mathrm{L}$ & 22 & $1-20 \mathrm{RU} / \mathrm{mL}$ & 39 & $5-9$ & 47 \\
\hline $0.1-0.2 \mathrm{~g} / \mathrm{L}$ & 52 & 10-100 RU/mL & 6 & $10-14$ & 29 \\
\hline $0.2-0.3 \mathrm{~g} / \mathrm{L}$ & 23 & $100-200 \mathrm{RU} / \mathrm{mL}$ & 3 & $15-25$ & 22 \\
\hline$>0.3 \mathrm{~g} / \mathrm{L}$ & 5 & $>200 \mathrm{RU} / \mathrm{mL}$ & 18 & $>25$ & 3 \\
\hline IgG & & & & & \\
\hline$<6 \mathrm{~g} / \mathrm{L}$ & 3 & $<1.0 \mathrm{~g} / \mathrm{L}$ & 5 & $<0.5 \mathrm{~g} / \mathrm{L}$ & 9 \\
\hline $6-10 \mathrm{~g} / \mathrm{L}$ & 15 & $1.0-2.0 \mathrm{~g} / \mathrm{L}$ & 24 & $0.5-1.5 \mathrm{~g} / \mathrm{L}$ & 64 \\
\hline $10-16 g / L$ & 33 & $2.0-4.0 \mathrm{~g} / \mathrm{L}$ & 48 & $1.5-2.5 \mathrm{~g} / \mathrm{L}$ & 16 \\
\hline $16-30 \mathrm{~g} / \mathrm{L}$ & 38 & $4.0-6.0 \mathrm{~g} / \mathrm{L}$ & 14 & $2.5-3.5 \mathrm{~g} / \mathrm{L}$ & 4 \\
\hline$>30 \mathrm{~g} / \mathrm{L}$ & 28 & $>6.0 \mathrm{~g} / \mathrm{L}$ & 26 & $>3.5 \mathrm{~g} / \mathrm{L}$ & 24 \\
\hline ANA titer & & & & & \\
\hline$<100$ & 6 & Yes & 115 & Yes & 36 \\
\hline $100-400$ & 42 & No & 2 & No & 81 \\
\hline $400-1000$ & 26 & NCA & & $\mathrm{NCA}$ & \\
\hline $1000-4000$ & 14 & Yes & 56 & Yes & 17 \\
\hline$>4000$ & 29 & No & 61 & No & 100 \\
\hline SSA & & & & ONA & \\
\hline Yes & 81 & Yes & 36 & Yes & 77 \\
\hline No & 36 & No & 81 & No & 60 \\
\hline RO52 & & RNP & & & \\
\hline Yes & 77 & Yes & 52 & Yes & 14 \\
\hline No & 40 & No & 65 & No & 103 \\
\hline JO-1 & & NP-B & & i-histone antibc & \\
\hline Yes & 12 & Yes & 21 & Yes & 46 \\
\hline No & 105 & No & 96 & No & 71 \\
\hline
\end{tabular}


Table 6: Relationship between SLE symptoms and indexes of renal functions and blood

\begin{tabular}{|c|c|c|c|c|c|c|c|c|c|c|}
\hline & \multicolumn{10}{|c|}{$\left|\beta_{\mathrm{j}}\right|$ value } \\
\hline & Creatinine & BUN & Albuminuria & Cylindruria & Hematuria & Pyuria & WBC & PLT & RBC & $\mathbf{H b}$ \\
\hline Facial redness & 0.0000 & 0.0000 & 0.0000 & 0.0000 & 0.0000 & 0.0000 & 0.0000 & 0.0000 & 0.0000 & 0.0000 \\
\hline $\begin{array}{l}\text { Rush in trunk } \\
\text { and limbs }\end{array}$ & 0.0000 & 0.0000 & 0.0001 & 0.0002 & 0.0000 & 0.0000 & 0.000 & 0.0000 & 0.0000 & 0.0000 \\
\hline Arthralgia & 0.0000 & 0.0000 & 0.0000 & 0.0000 & 0.0002 & 0.0001 & 0.0000 & 0.0000 & 0.0000 & 0.0000 \\
\hline Arthritis & 0.0000 & 0.0000 & 0.0000 & 0.0000 & 0.0001 & 0.0000 & 0.0000 & 0.0000 & 0.0000 & 0.0000 \\
\hline Photaesthesia & 0.0000 & 0.0000 & 0.0000 & 0.0000 & 0.0000 & 0.0000 & 0.0000 & 0.0000 & 0.0000 & 0.0000 \\
\hline Oral ulcer & 0.0000 & 0.0000 & 0.0000 & 0.0000 & 0.0000 & 0.0000 & 0.0000 & 0.0000 & 0.0000 & 0.0000 \\
\hline Thirst & 0.0000 & 0.0000 & 0.0000 & 0.0000 & 0.0000 & 0.0000 & 0.0000 & 0.0000 & 0.0000 & 0.0000 \\
\hline Dryness of eye & 0.0000 & 0.0000 & 0.0000 & 0.0000 & 0.0000 & 0.0000 & 0.0000 & 0.0000 & 0.0000 & 0.0000 \\
\hline Alopecia & 0.0000 & 0.0000 & 0.0000 & 0.0000 & 0.0000 & 0.0003 & 0.0000 & 0.0000 & 0.0000 & 0.0000 \\
\hline Fever & 0.0000 & 0.0000 & 0.0000 & 0.0001 & 0.0000 & 0.0002 & 0.0000 & 0.0000 & 0.0007 & 0.0000 \\
\hline $\begin{array}{l}\text { Raynaud } \\
\text { phenomenon }\end{array}$ & 0.0000 & 0.0000 & 0.0000 & 0.0000 & 0.0002 & 0.0000 & 0.0000 & 0.0000 & 0.0002 & 0.0000 \\
\hline Pericarditis & 0.0000 & 0.0000 & 0.0000 & 0.0000 & 0.0000 & 0.0000 & 0.0000 & 0.0000 & 0.0000 & 0.0000 \\
\hline Pleurisy & 0.0000 & 0.0064 & 0.0000 & 0.0000 & 0.0000 & 0.0000 & 0.0000 & 0.0000 & 0.0045 & 0.0168 \\
\hline $\begin{array}{l}\text { Multiple } \\
\text { serositis }\end{array}$ & 0.0000 & 0.0000 & 0.0000 & 0.0000 & 0.0000 & 0.0000 & 0.0000 & 0.0000 & 0.0000 & 0.0000 \\
\hline Oedema & 0.0000 & 0.0000 & 0.0198 & 0.1170 & 0.0000 & 0.0000 & 0.0000 & 0.000 & 0.0000 & 0.0000 \\
\hline
\end{tabular}

Data was analysed by adaptive lasso analysis, and $\left|\beta_{\mathrm{j}}\right|$ value $>0.001$ was considered as significant. 
Table 7: Relationship between lupus symptoms and liver functions indexes

\begin{tabular}{|c|c|c|c|c|c|c|c|c|c|c|c|}
\hline & \multicolumn{11}{|c|}{$\left|\beta_{\mathrm{j}}\right|$ value } \\
\hline & TC & TG & HDL & LDL & $\begin{array}{c}\text { Liver } \\
\text { damage }\end{array}$ & ALB & GLO & ALT & AST & GGT & ALP \\
\hline Facial redness & 0.0000 & 0.0000 & 0.0000 & 0.0000 & 0.0000 & 0.0000 & 0.0000 & 0.0000 & 0.0000 & 0.0000 & 0.0000 \\
\hline $\begin{array}{l}\text { Rush in trunk } \\
\text { and limbs }\end{array}$ & 0.0000 & 0.0000 & 0.0000 & 0.0000 & 0.0000 & 0.0000 & 0.0000 & 0.0000 & 0.0000 & 0.0000 & 0.0000 \\
\hline Arthralgia & 0.0000 & 0.0000 & 0.0000 & 0.0000 & 0.0000 & 0.0000 & 0.0000 & 0.0000 & 0.0000 & 0.0000 & 0.0000 \\
\hline Arthritis & 0.0000 & 0.0000 & 0.0000 & 0.0000 & 0.0000 & 0.0000 & 0.0000 & 0.0000 & 0.0000 & 0.0000 & 0.0000 \\
\hline Photaesthesia & 0.0000 & 0.0000 & 0.0000 & 0.0000 & 0.0000 & 0.0000 & 0.0000 & 0.0000 & 0.0000 & 0.0000 & 0.0000 \\
\hline Oral ulcer & 0.0000 & 0.0000 & 0.0000 & 0.0000 & 0.0000 & 0.0000 & 0.0000 & 0.0000 & 0.0000 & 0.0000 & 0.0000 \\
\hline Thirst & 0.0000 & 0.0000 & 0.0000 & 0.0000 & 0.0000 & 0.0000 & 0.0000 & 0.0000 & 0.0000 & 0.0000 & 0.0000 \\
\hline Dryness of eye & 0.0000 & 0.0000 & 0.0000 & 0.0000 & 0.0000 & 0.0000 & 0.0000 & 0.0000 & 0.0000 & 0.0000 & 0.0000 \\
\hline Alopecia & 0.0001 & 0.0000 & 0.0002 & 0.0000 & 0.0033 & 0.0000 & 0.0000 & 0.0000 & 0.0104 & 0.0000 & 0.0000 \\
\hline Fever & 0.0000 & 0.0003 & 0.0000 & 0.0000 & 0.0011 & 0.0000 & 0.0000 & 0.0001 & 0.0000 & 0.0000 & 0.0000 \\
\hline $\begin{array}{l}\text { Raynaud } \\
\text { phenomenon }\end{array}$ & 0.0003 & 0.0012 & 0.0000 & 0.0000 & 0.0002 & 0.0000 & 0.0000 & 0.0000 & 0.0000 & 0.0000 & 0.0000 \\
\hline Pericarditis & 0.0000 & 0.0000 & 0.0000 & 0.0000 & 0.0000 & 0.0000 & 0.0000 & 0.0000 & 0.0000 & 0.0000 & 0.0000 \\
\hline Pleurisy & 0.0000 & 0.0000 & 0.0000 & 0.0000 & 0.0000 & 0.0000 & 0.0000 & 0.0000 & 0.0000 & 0.0000 & 0.0000 \\
\hline $\begin{array}{l}\text { Multiple } \\
\text { serositis }\end{array}$ & 0.0000 & 0.0000 & 0.0000 & 0.0000 & 0.0000 & 0.0000 & 0.0000 & 0.0000 & 0.0000 & 0.0000 & 0.0000 \\
\hline Oedema & 0.0000 & 0.0000 & 0.0000 & 0.0000 & 0.0000 & 0.0000 & 0.0000 & 0.0000 & 0.0000 & 0.0000 & 0.0000 \\
\hline
\end{tabular}

Data was analysed by adaptive lasso analysis, and $\left|\beta_{\mathrm{j}}\right|$ value $>0.001$ was considered as significant. 
Table 8: Relationship between lupus symptoms and immunological indexes \& SLEDAI scores

\begin{tabular}{|c|c|c|c|c|c|c|c|c|c|c|c|c|c|c|c|c|}
\hline & \multicolumn{16}{|c|}{$\left|\beta_{\mathrm{j}}\right|$ value } \\
\hline & $\mathbf{C 3}$ & $\mathrm{C4}$ & IgG & $\operatorname{IgA}$ & IgM & ANA & dsDNA & Sm & AnuA & u1RNP & SSA & SSB & RO52 & CENP & $\begin{array}{c}\text { Anti- } \\
\text { histone } \\
\text { antibadv }\end{array}$ & SLEDAI \\
\hline Facial redness & 0.0000 & 0.0001 & 0.0000 & 0.0000 & 0.0000 & 0.0002 & 0.0000 & 0.0000 & 0.0000 & 0.0000 & 0.3580 & 0.0000 & 0.0000 & 0.0000 & 0.0000 & 0.0000 \\
\hline $\begin{array}{l}\text { Rush in trunk } \\
\text { and limbs }\end{array}$ & 0.0000 & 0.0001 & 0.0000 & 0.0000 & 0.0000 & 0.0000 & 0.0000 & 0.0000 & 0.0000 & 0.0000 & 0.0000 & 0.0000 & 0.0000 & 0.0000 & 0.0000 & 0.0000 \\
\hline Arthralgia & 0.0000 & 0.0001 & 0.0000 & 0.0000 & 0.0000 & 0.0000 & 0.0000 & 0.0001 & 0.0000 & 0.0000 & 0.0047 & 0.0000 & 0.0003 & 0.0001 & 0.0000 & 0.0000 \\
\hline Arthritis & 0.0000 & 0.0000 & 0.0000 & 0.0000 & 0.0000 & 0.0000 & 0.0000 & 0.0000 & 0.0038 & 0.0000 & 0.0000 & 0.0000 & 0.0000 & 0.0000 & 0.0000 & 0.0000 \\
\hline Photaesthesia & 0.0000 & 0.0000 & 0.0000 & 0.0000 & 0.0000 & 0.0000 & 0.0000 & 0.0000 & 0.0000 & 0.0000 & 0.0000 & 0.0002 & 0.0000 & 0.0003 & 0.0000 & 0.0000 \\
\hline Oral ulcer & 0.0000 & 0.0000 & 0.0000 & 0.0000 & 0.0000 & 0.0001 & 0.0000 & 0.0000 & 0.0000 & 0.0000 & 0.0000 & 0.0000 & 0.0000 & 0.0000 & 0.0000 & 0.0000 \\
\hline Thirst & 0.0000 & 0.0000 & 0.0000 & 0.0000 & 0.0000 & 0.0000 & 0.0000 & 0.0000 & 0.0000 & 0.0000 & 0.0000 & 0.0000 & 0.0000 & 0.0000 & 0.0000 & 0.0000 \\
\hline Dryness of eye & 0.0000 & 0.0000 & 0.0000 & 0.0000 & 0.0000 & 0.0000 & 0.0000 & 0.0000 & 0.0000 & 0.0000 & 0.0000 & 0.0000 & 0.0000 & 0.0000 & 0.0000 & 0.0000 \\
\hline Alopecia & 0.0000 & 0.0000 & 0.0000 & 0.0000 & 0.0000 & 0.0000 & 0.0000 & 0.0000 & 0.0000 & 0.0000 & 0.0000 & 0.0001 & 0.0000 & 0.0001 & 0.0000 & 0.0000 \\
\hline Fever & 0.0000 & 0.0005 & 0.0000 & 0.0001 & 0.0000 & 0.0000 & 0.0001 & 0.0000 & 0.0000 & 0.0000 & 0.0004 & 0.0000 & 0.0000 & 0.0000 & 0.0000 & 0.0000 \\
\hline $\begin{array}{l}\text { Raynaud } \\
\text { phenomenon }\end{array}$ & 0.0002 & 0.0001 & 0.0000 & 0.0000 & 0.0000 & 0.0000 & 0.0000 & 0.0000 & 0.0000 & 0.0012 & 0.0000 & 0.0005 & 0.0000 & 0.0000 & 0.0000 & 0.0000 \\
\hline Pericarditis & 0.0000 & 0.0000 & 0.0000 & 0.0000 & 0.0000 & 0.0000 & 0.0000 & 0.0000 & 0.0026 & 0.0000 & 0.0000 & 0.0000 & 0.0000 & 0.0000 & 0.0000 & 0.0000 \\
\hline Pleurisy & 0.0000 & 0.0000 & 0.0000 & 0.0000 & 0.0000 & 0.0001 & 0.0000 & 0.0000 & 0.0000 & 0.0000 & 0.0000 & 0.0000 & 0.0000 & 0.0000 & 0.0000 & 0.0413 \\
\hline Multiple serositis & 0.0000 & 0.0000 & 0.0000 & 0.0000 & 0.0000 & 0.0000 & 0.0000 & 0.0000 & 0.0048 & 0.0000 & 0.0000 & 0.0000 & 0.0000 & 0.0000 & 0.0000 & 0.0000 \\
\hline Oedema & 0.0000 & 0.0000 & 0.0000 & 0.0000 & 0.0000 & 0.0002 & 0.0000 & 0.0000 & 0.0000 & 0.0000 & 0.0000 & 0.0000 & 0.0000 & 0.0000 & 0.0000 & 0.0518 \\
\hline
\end{tabular}

Data was analysed by adaptive lasso analysis, and $\left|\beta_{\mathrm{j}}\right|$ value $>0.001$ was considered as significant. 